\title{
Chinese practices of The Initiative on Promoting Inter-ethnic Unity and Common Progress
}

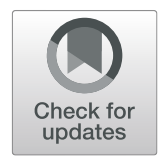

\author{
Qing Sui $\cdot$ Zhongxie Li $\cdot$ Shuyi Sun $\mathbb{D} \cdot$ Shiqiang Li $\cdot$ Danhong Chen
}

Received: 15 November 2019 / Accepted: 24 January 2020 / Published online: 05 February 2020 (C) The Author(s). 2020 Open Access This article is distributed under the terms of the Creative Commons Attribution 4.0 International License (http://creativecommons.org/licenses/by/4.0/), which permits unrestricted use, distribution, and reproduction in any medium, provided you give appropriate credit to the original author(s) and the source, provide a link to the Creative Commons license, and indicate if changes were made.

\begin{abstract}
The work of Initiative on Promoting Inter-ethnic Unity and Common Progress (hereinafter referred to as "The Initiative Work") originated from longterm historical practice and is a significant measure for China to promote interethnic unity and progress. This article sorts out the development process of The Initiative Work in China, introduces the progress of its demonstration regions and units, elaborates the practices of The Initiative Work in the following aspects: consolidation of the top-level design, improvement of the quality and coverage, publicity of the national policies, cultivation of the demonstration models, management by the laws, and strengthening theoretical studies. This article also analyzes the shortcomings and challenges faced by the current work.
\end{abstract}

\section{Introduction}

Solidarity is an important concept and discourse in modern society. Western society were the first to start social science research on solidarity. Solidarity theory is embodied in a series of theories of political science, philosophy, anthropology, and sociology in the construction of nation-state, communitarianism, multiculturalism, and minority rights, intertwined with concepts such as community and identity.

Solidarity in the modern sense intertwined with Chinese society and its knowledge system, gives rise to the meaning of solidarity with Chinese characteristics. China's inter-ethnic unity (which means solidarity among all ethnic groups) is the

Q. Sui $\cdot$ Z. Li $\cdot$ S. Sun $(\bowtie) \cdot S$. Li $\cdot$ D. Chen

Promoting Ethnic Unity and Common-progress Innovatively Activity Guidance Office by Department of Inspection and Supervision National Ethnic Affairs Commission, P.R, Jia 49 Fuxingmennei Ave,

Western District, Beijing 100080, China

e-mail:sunshu3@sina.com 
embodiment of the Sinicization of the Marxist ethnic theory and important experience in solving ethnic problems with Chinese characteristics. Since the founding of the People's Republic of China, inter-ethnic unity has gradually sunk from the principle of construction of a multi-ethnic country into policy practice and social rules. With economic and social development process of the whole country, it has more and more reflected the multidimensional characteristics of political unity, citizen unity and social unity (Yan 2019).

The work of Initiative on Promoting Inter-ethnic Unity and Common Progress is a policy practice advocated by the Chinese government, with the participation of local governmental departments and the whole society, which has been integrated into the process of economic and social development of the whole country. It is a basic ethnic work with extensive participation of the masses. It aims to promote the common unity and prosperity of all ethnic groups through comprehensive measures to consolidate and strengthen the socialism ethnic relations of equality, solidarity, mutual aid and harmony.

The Initiative Work originated from China's long-term historical practice and has been widely recognized and supported by cadres and people of all ethnic groups. The Initiative Work has made an active exploration on how to give full play to the dominant position of the masses of all ethnic groups in the governance of ethnic affairs and to promote the modernization of the governance of ethnic affairs.

In 2011, Huang Hongmei and Zhang Yong reviewed and combed The Initiative Work from the perspective of the development of inter-ethnic unity and progress. ${ }^{1}$ In 2013, Wu Xiao analyzed the composition, characteristics and operation of the mechanism of The Initiative Work, and concluded that the practice of The Initiative Work is in line with the theory of governance. (Wu 2013) In 2018, the Supervision and Inspection Department of the National Ethnic Affairs Commission of the People's Republic of China, in conjunction with the commemoration of the 40th anniversary of reform and opening-up, summarized the experience of The Initiative Work since $1979 .^{2}$ This article attempts to systematically comb through the practice of The Initiative Work from the historical perspective, explores the characteristics of the work itself and the objective laws that drive the evolution, in order to better examine the shortcomings and problems facing us at present, and to promote further progress of inter-ethnic unity.

\footnotetext{
${ }^{1}$ Huang Hongmei and Zhang Yong (黄红梅, 张勇). The History and Enlightenment of The Initiative on Promoting Inter-ethnic Unity and Common Progress 我国民族团结进步事业创建历程与启示, December 16, 2011. China Ethnic News 《中国民族报》.

${ }^{2}$ The Supervision and Inspection Department of the National Ethnic Affairs Commission of the People's Republic of China 国家民委监督检查司. Resonating with the Times, Deepening The Initiative on Promoting Inter-ethnic Unity and Common Progress 与时代同频共振, 深化民族团结进步创建, October 9, 2018. China Ethnic News《中国民族报》.
} 
The development of the initiative on promoting inter-ethnic unity and common progress

Germination and origination (from the late 1940s to the 1970s): the central government advocated inter-ethnic unity through policy practice, and a local government started the Initiative activities

Since the founding of the People's Republic of China, China has been affirmed as a unified multi-ethnic country. It regards ethnic equality and inter-ethnic unity as important principles for nation-building, and established the system of regional ethnic autonomy as a basic state policy and political system. As stipulated in the Common Program of the Chinese National Political Consultative Conference, which had the function of an interim constitution:

Article 50 All nationalities within the boundaries of the People's Republic of China are equal. They shall establish unity and mutual aid among themselves, and shall oppose imperialism and their own public enemies, so that the People's Republic of China will become a big fraternal and co-operative family composed of all its nationalities. Greater Nationalism and chauvinism shall be opposed. Acts involving discrimination, oppression and splitting of the unity of the various nationalities shall be prohibited.

In order to implement the principles of ethnic equality and inter-ethnic unity, on the one hand, since the summer of 1950, the Chinese government had set up a Central Delegation with 4 branches to visit ethnic minorities in China. More than one hundreds people from over 20 units joined in the delegation. They came from institutions including the Central Ethnic Affairs Commission, the Committee on Culture and Education, the Ministry of the Interior, the Ministry of Health, the Ministry of Trade and the Central Committee of the Youth League. The four delegation branches were sent respectively to the ethnic regions in Southwest China, Northwest China, South and Central China, and Northeast China to visit ethnic groups in more than 10 provinces including Xikang, Xinjiang, Guangxi, and Inner Mongolia and so on. The Central Delegation launched research in ethnic areas, implemented ethnic work almost in all aspects including policy propaganda, economic aid, equal trade solution, cultural exchanges, health support, establishment of Autonomous regions for ethnic minorities, training cadres of ethnic minorities. The visits and surveys of the Central Delegation have also contributed to the social and historical survey, language survey and ethnic identification work of ethnic minorities. The results of the surveys, Five Series of Books on Ethnic Issues, ${ }^{3}$ affirmed that the history of each ethnic minority is part of the history of the People's Republic of China and provided a scientific basis for the implementation of regional ethnic autonomy system. On the other hand, in the same year, the Chinese government invited groups of ethnic minorities to Beijing to participate in the National Day ceremony. The two-way communication and exchanges strengthened the ties between the central government 
and remote ethnic minorities, initiated comprehensive ethnic work there, broke historical inter-ethnic barriers.

The origin of The Initiative Work was born in such a context. It was a local government that first advocated activities of inter-ethnic unity. In 1953, Yanbian Korean Autonomous Prefecture of Jilin Province held the first Inter-ethnic Unity Model Representative Conference. It took the lead in deciding to designate September as "Inter-ethnic Unity Propaganda Month," which concentrated on publicizing the Party's ethnic theory and policy, and carried out inter-ethnic unity activities for the people of all ethnic groups in the prefecture.

In 1956, Mao Zedong made it clear in his speech, On Ten Relations, that the policy on the relationship between the Han and ethnic minorities was relatively stable, and it was approved by the ethnic minorities. Since 1958, the top-down notion of promoting inter-ethnic unity and common progress undergone serious concussion, but the practice of different forms of inter-ethnic unity still continues. A much-told tale of inter-ethnic unity in China at that time goes like this: In the early 1960s, China experienced a famine and a severe shortage of food. Some orphanages in southern china, such as Shanghai and Jiangsu, were in trouble because of food shortages. More than 3000 young orphans were malnourished. More and more got sick. The Party Committee of Inner Mongolia Autonomous Region accepted and raised these orphans in accordance with the instructions of the Party Central Committee. More than 3000 orphans were re-settled with families in Inner Mongolia.

\section{Exploration and development: from 1978 to 2009}

After the reform and opening up, China's ethnic policy was reaffirmed, which determined inter-ethnic unity to be the main tasks of ethnic work in the new period. It has also re-launched the publicity campaign for the concept of inter-ethnic unity that was initiated by the central government, responded by the local governments at all levels, and participated by the people throughout the country. It required that "among the people of all ethnic groups, the implementation of ethnic policy should be carefully examined, the problems existing in inter-ethnic relations should be effectively solved, and the factors that are not conducive to inter-ethnic unity should

\footnotetext{
${ }^{3}$ Five Series of Books on Ethnic Issues《民族问题五种从书》, is refers to Series of Books on the Ethnic Minorities of the People's Republic of China, Series of Books on a Brief History of Ethnic Minorities in China, Series of Books on Brief Introduction to Languages of Ethnic Minorities in China, Series of Books on Brief Introduction to China's Ethnic Minority Autonomous Regions, Series of Books on Data Collected from China's National-wide Survey on Society and History of Ethnic Minorities, which is the important achievements of the first national-wide survey of ethnic minorities, presided over by the State Ethnic Affairs Commission of the People's Republic of China. The original edition of the series consists of 402 books, more than 100 million words, published by more than 30 publishing houses in China. The publishing of the Five Series of Ethnic Issues started in 1958 and was completed in 1991, more than 400 writing teams from 19 provinces, autonomous regions, municipalities participated in the writing, with more than 1760 participants. It is a veritable encyclopedia of the study of Chinese ethnic issues, involving regional ethnic autonomy, ethnic history, ethnology, ethnic language, ethnic economy, ethnic literature, religion, medicine, sports, dance, painting and other subjects. It is the only book series in the world that is organized by the government, widely participated by social forces, which comprehensively and systematically reflects the situation of Chinese ethnic minorities. The revision and republication began in 2005 .
} 
be eliminated." In 1983, the Xinjiang Uygur Autonomous Region designated May as "Inter-ethnic Unity Publicity Month" and the Inner Mongolia Autonomous Region designated September as "Inter-ethnic Unity Commendation Month". Though these activities, people of all ethnic groups have learned about the Party's ethnic policies and knowledge about other ethnic groups, they carried out cultural and recreational activities with different ethnic groups, which strengthened their emotional exchanges.

The promulgation and implementation of the Law of the People's Republic of China on Regional National Autonomy in 1984 brought ethnic work into an era of legalization. After the reform and opening up, the focus of ethnic work shifted to socialist modernization, but inter-ethnic unity remained the focus of ethnic work. In order to comply with the requirements of economic and social development, inter-ethnic unity was beginning to be integrated in the economic, cultural and social construction, which promoted the common prosperity and progress of all ethnic groups. In 1988, the first Inter-ethnic Unity Commendation Conference was held in Beijing to recognize the collectives and individuals who had contributed to the cause of inter-ethnic unity and progress. In 2005, the Inter-ethnic Unity Commendation Campaign was officially identified as a statutory activity of the State. ${ }^{4}$

On March 4, 2003, President Hu Jintao pointed out during the 10th session of the National Committee of the Chinese People's Political Consultative Conference that, "To achieve the grand goal of building a well-off society in an all-round way is to better realize the common prosperity and development of all ethnic groups. To achieve the common prosperity and development of all ethnic groups requires the common unity and struggle of all ethnic groups. Together, the theme of ethnic work in the new century is to unite and strive for the common prosperity and development of all ethnic groups." 5 In 2006, the National People's Committee launched the evaluation and naming of the National Education Base for interethnic unity and Progress. ${ }^{6}$

\section{Confirmative establishment and comprehensive promotion: from 2009 to present}

In September 2009, at the Fifth National Congress for the Promotion of Interethnic Unity and Progress held by the State Council, President Hu Jintao pointed out that "The Initiative on Promoting Inter-ethnic Unity and Common Progress, and commendation activities should be carefully organized". ${ }^{7}$ For the first time, the

\footnotetext{
${ }^{4}$ National Ethnic Affairs Commission of the People's Republic of China国家民族事务委员会. 2015. Central Ethnic Work Conference Spiritual Learning Counseling Reader 《中央民族工作会议精神学习 辅导读本》, The Ethnic Publishing House.

${ }^{5}$ National Ethnic Affairs Commission of the People's Republic of China 国家民族事务委员会 and Literature Research Office of the Central Committee of the Communist Party of China 中共中央文献研 究室. 2010. Common Unity and Struggle, Common Prosperity and Development 共同团结奋斗, 共同 繁荣发展, Selected Works of Ethnic Work《民族工作文献选编》. Central Party Literature Press. p.2-3.

${ }^{6}$ In October 2013, The Nomination Method for the Evaluation of Ethnic Unity and Progress Bases 《全 国民族团结进步教育基地评审命名办法》was promulgated and implemented in the form of a decree by the National Ethnic Affaires Commission of the People's Republic of China. By the end of 2016, five batches of 165 Inter-ethnic Unity and progress bases had been nominated.
} 
concept of The Initiative on Promoting Inter-ethnic Unity and Common Progress was clearly put forward. In March 2010, the Publicity Department of the Communist Party of China, the United Front Work Department of the CPC Central Committee and the National Ethnic Affairs Commission jointly issued the Opinions on Further Developing The Initiative on Promoting Inter-ethnic Unity and Common Progress. All regions have made active efforts and explorations in perfecting the working mechanism of activities, strengthening the training and propaganda of typical cases, grasping the key points of work and enriching the working forms.

In August 2011, the National Ethnic Affairs Commission of the PRC set up an activity guidance office in the Division of Supervision and Inspection to promote The Initiative Work throughout the country. The National Ethnic Affairs Commission of the People's Republic of China, together with the Ministry of Civil Affairs of PRC and the State-owned Assets Supervision and Administration Commission, has formulated the Opinions on Strengthening the Ethnic Work of Communities under the New Situation and the Guiding Opinions on Further Improving the Ethnic Work of State-Owned Enterprises under the New Situation, to carry out work in the community and state-owned enterprises.

In June 2012, the Publicity Department of the Communist Party of China, the United Front Work Department of the CPC Central Committee and the National Ethnic Affairs Commission jointly held a conference of "National Experience Exchange Conference of Initiative on Promoting Inter-ethnic Unity and Common Progress" in Yinchuan, capital city of the Ningxia Hui Autonomous Region. In July, the 12th Five-Year Plan for Ethnic Minority Programming issued by the State Council called for the establishment of a number of demonstration units for interethnic unity and progress during the 12th Five-Year Plan period.

In September 2014, the Fourth Central Conference on Ethnic Work and the Sixth National Congress of the State Council for the Recognition of Inter-ethnic Unity and Progress were held in Beijing. Xi Jinping, General Secretary of the Central Committee of the Communist Party of China, President of the State and Chairman of the Central Military Commission, delivered important speeches at the meeting. He attached great importance to the work of inter-ethnic unity. He clearly pointed out that inter-ethnic unity is the lifeline of all ethnic groups in China and that, to do a good job in ethnic work, the most important thing is to do a good job in inter-ethnic unity, and the most useful thing is to win people's hearts and minds. The meeting proposed that "Innovative carriers and approaches to the work of inter-ethnic unity should be explored to guide the people of all ethnic groups to firmly establish a correct concept of motherland, of history and of ethnicity, and consciously safeguard the best interests of the country and the overall situation of inter-ethnic unity". 8

The 13th Five-Year Plan for Promoting the Development of Minority Areas and Minorities with Less Population issued by the State Council in 2016 and The 13th

\footnotetext{
${ }^{7}$ National Ethnic Affairs Commission of the People's Republic of China 国家民族事务委员会 and Literature Research Office of the Central Committee of the Communist Party of China 中共中央文献研 究室. 2010. Common Unity and Struggle, Common Prosperity and Development 共同团结奋斗, 共同 繁荣发展, Selected Works of Ethnic Work《民族工作文献选编》. Central Party Literature Press. p.406.
} 
Five-Year Plan for the prosperity of border areas and people issued by the General Office of the State Council in 2017 made specific arrangements for launching. In 2017, the Publicity Department of the Communist Party of China, the United Front Work Department of CPC Central Committee and the National Ethnic Affairs Commission held the "National Initiative on Promoting Inter-ethnic Unity and Common Progress Experience Exchange Meeting" in Xing'an League, the Inner Mongolia Autonomous Region, which explicitly upgraded the "Initiative Activity" to "Initiative Work" " and strengthened the foundation and long-term nature of the creation work.

Construction of demonstration zones and demonstration unites on the initiative on promoting inter-ethnic unity and common progress

In the multi-ethnic country of China, promoting the construction of initiative demonstration regions (units) and setting up advanced models has been employed as important carriers in deepening and extending The Initiative on Promoting Inter-ethnic Unity and Common Progress. They are important platforms for strengthening the ethnic work under the new situation and promoting exchanges and communications among all ethnic groups.

In June 2012, the National Ethnic Affairs Commission, the Publicity Department of the Communist Party of China and the United Front Work Department of the CPC Central Committee held a national experience exchange conference on The Initiative Work and nominated the first 35 national demonstration units of The Initiative on Promoting Inter-ethnic Unity and Common Progress.

In 2014, the National Ethnic Affairs Commission issued a document, which formulated the national evaluation indicators of demonstration units for all prefecturelevel administrative units (prefectures, prefecture-level cities and leagues), all countylevel administrative units (county-level cities, districts and banners) and units below county-level. With reference to the above mentioned indicators, some provinces and autonomous regions have also formulated the evaluation indicators of provincial and regional-level demonstration units in light of local realities. In 2014, the Central Conference on Ethnic Work emphasized that "a large number of communities, villages, units, schools, companies, etc., which can play a demonstration role should be established." In a word, all sectors of the community should be mobilized to implement The Initiative Work in order for them to contribute to the work by promoting and helping ethnic minorities and ethnic areas with the integration of economic and social development. by addressing the vital interests of all ethnic groups, by identifying and resolving factors of instability, by doing a good job in the actual work of local areas and local departments.

\footnotetext{
${ }^{8}$ The Central Ethnic Work Conference and State Council's Sixth Inter-ethnic Unity and Progress Awards Conference 中央民族工作会议暨国务院第六次全国民族团结进步表彰大会举行， September 29, 2019, http://www.gov.cn/xinwen/2014-09/29/content_2758816.htm.

${ }^{9}$ The Supervision and Inspection Department of the National Ethnic Affairs Commission of the People's Republic of China 国家民委监督检查司. Resonating with the Times, Deepening The Initiative on Promoting Inter-ethnic Unity and Common Progress 与时代同频共振, 深化民族团结进步创建, October 9, 2018. China Ethnic News 《中国民族报》.
} 


\section{Evaluation and nomination of national demonstration regions (units)}

The evaluation and nomination of the demonstration regions (units) was organized and implemented by the National Ethnic Affairs Commission. According to the national evaluation indicators, first, regions and departments submit their recommended list, then, a group of experts and scholars in the ethnic research field conduct a preliminary evaluation on the recommended lists, finally, departments of the National Ethnic Affairs Commission are to eliminate the units that have ecological and security problems from the lists, and send teams on random spot check. The candidate list will be publicized in the media, and will be named after the expiration of the publicity period. By October 2019, six batches of 899 demonstration regions (units) at all levels were nominated. The nomination has three characteristics. Firstly, the demonstration regions (units) cover more abundant types, including both ethnic areas and mixed ethnic areas; both county, city, district and rural communities; both government departments, enterprises, schools, troops, and railways, hospitals, temples, scenic spots, new social organizations, and so on. Secondly, in central and eastern China, nominations are mainly given to grass-roots units. In the western regions of China, nominations will focus on promoting overall regional and cross-regional cooperation, and on the establishment of advanced zones and demonstration zones at the provincial and district levels. Thirdly, there has been increased support to encourage The Initiative Work by key regions, key industries and new economic organizations. For example, in 2017, China Railway Corporation nominated 15 units such as Yanji West Railway Station of Shenyang Railway Bureau. In 2018, China Railway Corporation nominated another 15 units such as Jiamusi depot of Harbin Group Corporation and called on all units of the Railway to learn from the experience of demonstration units.

\section{Construction of national demonstration prefectures (prefectures, prefecture-level} cities, leagues)

In September 2013, the National Ethnic Affairs Commission of the People's Republic of China held a pilot launching ceremony of The Initiative on Promoting Inter-ethnic Unity and Common Progress in Changji Hui Autonomous Prefecture of Xinjiang, and identified 13 pilot projects for ethnic unity and progress demonstration prefectures (prefectures, prefecture-level cities, leagues), including Ili Kazakh Autonomous Prefecture of Xinjiang Uygur Autonomous Region, Yanbian Korean Autonomous Prefecture of Jilin, Enshi Tujia and Miao Autonomous Prefecture of Hubei, Xiangxi Tujia and Miao Autonomous Prefecture of Hunan, Xishuangbanna Dai Autonomous Prefecture of Yunnan, Dali Bai Autonomous Prefecture of Yunnan, Linxia Hui Autonomous Prefecture of Gansu, Haibei Tibetan Autonomous Prefecture of Qinghai, Nanning City of Guangxi Zhuang Autonomous Region, Lhasa City of Tibet Autonomous Region, Wuzhong City of Ningxia Hui Autonomous Region, Tongren City of Guizhou, Xing'an League of Inner Mongolia Autonomous Region. The National Ethnic Affairs Commission of the People's Republic of China guides the pilot areas to integrate The Initiative Work closely with reality to achieve the seven major demonstration goals of ethnic 
work innovation, harmonious ethnic relations, and guarantee of people's livelihood, ethnic economic development, development of ethnic culture and education, foster of ethnic cadres and construction of ecological civilization. Thirteen regions have successfully achieved the goals and were nominated by the National Ethnic Affairs Commission of the People's Republic of China by the end of 2016.

Since 2017, the nomination of demonstration regions at the prefecture-level has been integrated into the evaluation and nomination system of national "Initiative on Promoting Inter-ethnic Unity and Common Progress Demonstration Regions/ Units." In 2017, after examination and acceptance by the United Front Work Department of the CPC Central Committee and the National Ethnic Affairs Committee, seven prefectures and cities including Sichuan Liangshan Yi Autonomous Prefecture, Yunnan Chuxiong Yi Autonomous Prefecture, Gannan Tibetan Autonomous Prefecture of Gansu Province, Xi'ning City of Qinghai Province, Haixi Mongolian Tibetan Autonomous Prefecture, Hainan Tibetan Autonomous Prefecture and Turpan City of Xinjiang Uygur Autonomous Region were nominated to be the "Initiative on Promoting Inter-ethnic Unity and Common Progress Demonstration Prefectures and Cities" by the National Ethnic Affairs Commission of the People's Republic of China . By October 2019, the National Ethnic Affairs Commission of the People's Republic of China had nominated 30 National Demonstration Prefectures (prefectures, prefecture-level cities and leagues) of The Initiative Work. The nominated National Demonstration Prefectures of The Initiative Work continued to promote the development of the work. For example, the Dali Bai Autonomous Prefecture of Yunnan has held seminars to further explore the "optimization of The Initiative Work " 10

Through the nomination of demonstrations regions and units at different levels and of different types, the demonstration scale is growing rapidly, and the social effect is becoming increasingly prominent. The leading role of demonstrations is mainly embodied in the following five aspects: First, they have promoted the publicity and implementation of the Chinese government's ethnic policies throughout the whole society, and maintained the unification of China. Second, they have carried forward the core values of socialism, and have consolidated and developed the socialist ethnic relations of equality, solidarity, mutual aid and harmony. Third, the demonstration regions and units have built a platform for exchanges and communication among different ethnic groups, and enhanced mutual understanding, mutual respect, mutual tolerance, mutual appreciation, mutual learning and mutual aid among all ethnic groups. Fourth, the sense of gain has been increased, and the atmosphere of inter-ethnic unity and social stability has been created. Fifth, the demonstration units have accumulated a lot of valuable experience to be referenced and promoted. For example, Dalian Nationalities University organized a scientific research team to help farmers in mountainous areas of Tongren City, Guizhou Province to effectively solve agricultural technical problem of low oil content and low yield of oil tea ${ }^{11}$; the ethnic work department of Beijing has

\footnotetext{
${ }^{10} \mathrm{Li}$ Zhongxie 李钟协. Experience and Enlightenment of Creating “Dali Samples" by Inter-ethnic Unity and Progress 民族团结进步创建“大理样本”的经验与启示, May 31, 2019. China Ethnic News《中国 民族报》。
} 
set up training courses with the particpant of volunteer teams to improve the national language level of ethnic minority workers in Beijing; Shanghai has set up service windows in the streets and communities where the migrant population of ethnic minorities is concentrated to help solve their difficulties in employment and schooling, and to promote integration into the city; Shenzhen established a legal aid station in 2012 to provide targeted professional legal aid to ethnic minorities. All kinds of experience and practices have been displayed and promoted through The Initiative Work platform, which have improved the ability and level of ethnic affair governance, and promoted the innovative practice of ethnic unity and progress.

Characteristics of the initiative on promoting inter-ethnic unity and common progress in contemporary China

Top-level design strengthened and new progress achieved in serving the overall situation

Since the 18th National Congress, the Chinese government has formulated a series of important policy documents related to ethnic work, forming a comprehensive policy system to guide The Initiative on Promoting Inter-ethnic Unity and Common Progress. Since 2012, the Initiative activities have been included in the evaluation index system of "Civilized Cities," with a proportion of 3.88 points in the evaluation. In 2019, the Central Committee requested to increase the weights of the Initiative in the founding of civilized cities in a timely manner. ${ }^{12}$ In recent years, The Initiative on Promoting Inter-ethnic Unity and Common Progress has been written into important documents such as the National Economic and Social Development Plan, National Education Development, Action Program for Vitalizing Border Areas and Enriching the People Living There, the Government Work Report and so on.

Most local Chinese governments have set up leading groups and issued specific implementation opinions. Ningxia, Gansu, Hu'nan and other provinces have issued special plans for The Initiative Work in the 13th Five-Year Plan. Beijing has issued The Initiative on Promoting Inter-ethnic Unity and Common Progress Three-year Action Plan (2018-2020). ${ }^{13}$ The National Ethnic Affairs Commission of the People's Republic of China has signed cooperation agreements with Yunnan Province and Qinghai Province on the construction of Demonstration Regions and Advanced Zones for inter-ethnic unity and progress. The Initiative Work has been more integrated into the central work of all-level governments.

\footnotetext{
${ }^{11}$ Wang Xinwei王新伟. Science and Technology Break the Problem of Revenue Increase 科技攻关破 增收难题, January 3, 2019. Economic Daily《中国民族报》.

${ }^{12}$ Opinions of the State Office of the People's Office on the Creation of a Comprehensive, In-Depth and Lasting Work on The Initiative on Promoting Inter-ethnic Unity and Common Progress中办国办印 发《关于全面深入持久开展民族团结进步创建工作铸牢中华民族共同体意识的意》, October 24 , 2019. People's Daily《人民日报》.
} 


\section{Quality improved and both coverage and charisma improved}

After 2014, building up the consciousness of the Chinese nation's community has become the main line of The Initiative Work. At the Sixth National Congress of Commendation for Inter-ethnic Unity and Progress, 61 units were commended by the State Council, accounting for $46 \%$ of the total number of nominated demonstration units. Regarding to the mode of The Initiative Work, the focus has been laid on ordinary times and grass-roots level, and thematic activities which are popular with the masses have been extensively carried out, which enriched The Initiative Work forms. In the aspect of the assessment of The Initiative Work, local governments have gradually explored and implemented quantifiable acceptance criteria. For the Initiative of Demonstration Cities, the Central United Front Department and the National Ethnic Affairs Commission also carried out on-site assessment before acceptance.

\section{The role of traditional ethnic festivals and that of the media have been brought into play}

By playing the role of traditional and new media, a social culture that promotes inter-ethnic unity is created. In some places, important commemorative days and ethnic festivals are combined with The Initiative Work. Guangxi, Guizhou, Hainan, Fujian and other provinces have combined the March Third Festival activities with the activity of The Month of Inter-ethnic Unity to carry out rich and colorful activities. Newspapers and periodicals such as China Ethnic News and China Nationality have launched special topics or columns to actively publicize and report the advanced deeds of the people of all ethnic groups in the cause of inter-ethnic unity and progress.

The internet has become an important carrier and platform for demonstrating the presences of all ethnic groups. The Initiative on Promoting Inter-ethnic Unity and Common Progress has been set up on the government website of the National Ethnic Affairs Commission of the People's Republic of China, and more than 300 pieces of information on The Initiative Work are kept up-to-date throughout the year. Information of The Initiative Work is regularly published by the government affairs WeChat platform of the National Ethnic Affairs Commission, and information on Inter-ethnic Unity and progress content is released through the government affairs websites, as well as WeChat, MicroBlogs and other channels related to the Initiative Work around the country.

\section{Participation by multi-level governments and all industries}

At the national level, a model recognition mechanism has been improved. The Party Central Committee and the State Council have repeatedly commended

\footnotetext{
${ }^{13}$ Beijing Launches Three-year Action Plan for The Initiative on Promoting Inter-ethnic Unity and Common Progress 北京出台民族团结进步创建三年行动计划, August 14, 2018. China Ethnic News《中国 民族报》.
} 
collective and individual models for inter-ethnic unity and progress, and stimulated the enthusiasm of cadres and masses of all ethnic groups to participate in the establishment. At the provincial, prefectural, and city level, Yunnan, Guangxi, Guizhou, Gansu, Qinghai, and other places have actively established provincial demonstration and advanced areas. Wuling Mountain area and other places have steadily promoted The Initiative Work across provinces and regions. In this way, the multilevel demonstration and The Initiative pattern of provinces, prefectures, counties and grass-roots units has generally been formed. Driven by the influence of Demonstration Regions and Units, touching stories of inter-ethnic unity and progress in various fields and regions continue to emerge, and the influence of the The Initiative work is growing, a good atmosphere of competing for The Initiative Work has been created.

\section{Governance in accordance with the law, and management with standardization}

With the acceleration of the overall process of governing the country according to law, The work of The Initiative on Promoting Inter-ethnic Unity and Common Progress has been written into the Party's laws, regulations, and policy documents, incorporating The Initiative Work as a regulation into all work fields, effectively improving the standardization level of the work. Relevant departments actively carry out supervision and inspection of the implementation of ethnic policies. All relevant departments and units actively participant in The Initiative Work, adhere to the concept of equal treatment, and safeguard the legitimate rights and interests of the people of all ethnic groups. Guizhou Province, the Xinjiang Uygur Autonomous Region, Autonomous Prefectures in Qinghai Province, Diqing Prefecture of Yunnan Province, Lhasa City of Tibet Autonomous Region and Ganzi Prefecture of Sichuan Province have issued special regulations on ethnic unity and progress.

\section{Theoretical research carried out}

The National Ethnic Affairs Commission pays special attention to the study of basic theoretical issues and major practical issues in the field of ethnic groups. It is necessary to give full play of the role of ethnic colleges and think tanks, to form the interaction between the government and academia, to establish a discourse system of socialist ethnic theory and policy with Chinese characteristics. In December 2013, the National Ethnic Affairs Commission convened the "Promotion Meeting of Theory and Practice Innovation of Ethnic Unity and Progress Activities in National Colleges and Universities for Nationalities" at the South-central Minzu University. The conference deployed the Initiative Work in national ethnic colleges and universities in the following ways: firstly, classrooms should be the main channel; secondly, campus culture construction should be the carrier; thirdly, social practice platforms should be built for teachers and students. In March 2015, The Initiative on Promoting Inter-ethnic Unity and Common Progress Activity Theory and Practice Innovation Research was officially published, and The Initiative Work has attracted increasing attention from academia. On December 19, 2017, Research Center of The Initiative Work held a symposium on "High-end Think 
Tank Construction of The Initiative on Promoting Inter-ethnic Unity and Common Progress" in Enshi Prefecture, Hubei Province.

Through the long-term joint efforts of all parties, The Initiative on Promoting Inter-ethnic Unity and Common Progress has accumulated valuable experience, summarized as follows:

1. Focus on the center and serve the overall situation Solving ethnic issues with Chinese characteristics way, The Initiative on Promoting Inter-ethnic Unity and Common Progress is closely integrated with the major work of the state and with the overall goal and task of ethnic work.

2. Persist in classified guidance and precise implementation policy Starting from reality and taking into account the differences and characteristics of different regions and units as a whole, it enhance the pertinence and effectiveness of our work because The Initiative Work not only has unify norms but also respects the initiative spirit of grass-roots units with highlight common themes and regional characteristics.

3. Persist in overall planning and demonstration leading Advance from different level and classification, and the principle of "pilot first, exemplary guidance guide" provides a timely summary of experience, expands publicity.

4. Persist in law-based and regulation-based principles in the initiative work

5. Persist in social mobilization and common participation

It is the key issue to guide all ethnic groups to participate in the governance of ethnic affairs in an orderly manner in accordance with the law, and gradually form a benign interaction between the government and the society.

The shortage and challenges of the initiative on promoting inter-ethnic unity and common progress

Although the establishment work has made substantial progress, there are still shortages and challenges in deepening The Initiative Work.

1. Insufficient understanding of The Initiative Work: Some places do not attach enough importance to the work, and the ideas, methods and abilities related to The Initiative Work need to be improved. Some places believe that the work is the responsibility of the ethnic work departments only. Some places think that The Initiative Work means only propaganda, which is not closely linked with their central work.

2. Ways and methods of the the initiative work need to be further developed and innovated. In some places, the content and form of the initiative work are uniform and dull, which lack of attraction or broad coverage

3. The institutionalization and standardization of the initiative work needs further improvement. Some original policy designs, institutional arrangements, working mechanisms, and evaluation systems need to be revised and improved 
4. The effectiveness of the initiative work needs to be further enhanced. Some places are satisfied with the initiative work only starting at the surface level, which makes it difficult to reach the masses and the hearts of the people

5. Joint efforts of the initiative work need to be further strengthened and coverage of the work need to be expanded

Creative approaches suggested to improve the work of the initiative on promoting inter-ethnic unity and common progress

At present, China's inter-ethnic unity work closely revolves around the theme of common solidarity, prosperity, and development, and adheres to the principle of "focusing on ordinary times, heart-to-heart talk, action, and basic level." In accordance with the general requirements, creative approaches suggested to improve the work of The Initiative as followed:

\section{Deepening publicity of ethnic unity and progress concept}

1. Strengthen the publicity of the concept of Chinese nation community. Through in-depth publicity, the masses of all ethnic groups are to understand the relationship among China, the Chinese nation, Chinese culture, Chinese civilization and all ethnic groups in China, to establish correct views of our state, of our nation, of religion, of history and of culture, and to realize that inter-ethnic unity is an important guarantee for the realization of the Chinese dream, so that the maintenance of inter-ethnic unity and the construction of a great motherland become the conscious action of everyone.

2. Inheritance and development of excellent traditional Chinese culture. Identifying Chinese culture that includes ethnic cultures, embodying the pluralism of ethnic cultures in the "unity" of Chinese culture forms a vivid situation for the harmonious development of the national culture. National spirit with patriotism as its core and spirit of the times with reform and innovation as its core are to be carried forward, The spirit and value of national culture are to be rediscovered. Excellent Chinese traditional culture are to be integrated into national education, moral construction, cultural creation, and production and life with a good social atmosphere for the transmission of excellent Chinese traditional culture.

3. Improve the carrier and mode of the publicity of the ethnic unity and progress. Museums, memorials and cultural centers are to be utilized in promoting and displaying national culture and spreading the concept of unity. New technologies and media, such as MicroBlogs, WeChat and microvideos, are to be widely used to encourage the production and dissemination of Publicity films for public welfare on ethnic unity and progress, and more productions of high-quality minority film, television plays, and cultural products are to be supported.

4. Expanding the network to publicize the concept of ethnic unity and progress. "Internet plus" action are to be promoted to build an internet platform for 
cultural exchange and sharing, to promote cultural exchange and mutual learning among ethnic groups.

\section{Promoting exchange and communication among ethnic groups}

1. Promote the establishment of a mutually embedded social structure and community environment. Policy guidance and institutional safeguards are to be improved so that urban communities can better accommodate ethnic groups and promote integration. Urban and rural communities are to be constructed as beautiful and sharing communities with the joint effort of residents of all ethnic groups. The whole society should create an atmosphere of respect for the customs and religious beliefs of every ethnic group.

2. Develop group activities with distinctive features. Open channels for multisubject participation, and focus on building a series of practical activities on the platform of "the Chinese Nation Is One Family". Activities of two-way visits, co-coperations and communication among all ethnic groups, are to be encouraged for cadres and masses of all ethnic groups to experience the motherland on the spot and experience the compatriot friendship of the great family of the Chinese nation in person. Major commemorative days such as traditional festivals of the various Chinese ethnic groups and the founding day of ethnic autonomous areas can be used to carry out multi-level, multifield and diversified ethnic friendship activities. Thematic activities of "colorful ethnic groups" tourism are to be developed to enhance the connotation of tourism history and ethnic culture.

Improve the level of the initiative on promoting inter-ethnic unity and common progress

1. Promote the further development of The Initiative Work. The focus of work should be lowered to the grass-roots level and the allocation of resources and input of power should be tilted to build a platform for more people to participate easily, with insistence on hierarchical creation and the promotion of cross-regional, cross-industry collaborative effort in The Initiative Work. We are to give priority to the participation of cadres, youth, intellectuals, believers and other groups, and increase the participation of key industries, window units and new economic organizations.

2. Promote the construction of demonstration zones and demonstration units. Demonstration zones and demonstration units should innovate their working methods and create experiences that can be replicated and promoted. We should promote demonstration regions at all levels to take the lead in achieving the synchronization of building a well-off society and modernization, homogeneity of public services, equal rights guaranteed by the rule of law, co-construction of spiritual homes, and social harmony and co-creation. We should highlight the main line of the Chinese nation's 
community consciousness, consolidate the achievements of industries such as railways and frontier defense, and actively explore and extend to other fields.

3. Improve the modernization level of ethnic affairs governance. We will implement the basic strategy of governing the country according to law and unswervingly use the law to safeguard and consolidate ethnic unity. We should improve the system of laws and regulations of ethnic work, uphold equality before the law, and safeguard the legitimate rights and interests of citizens of all ethnic groups according to the law. We must resolutely crack down on illegal and criminal acts that undermine inter-ethnic unity and create ethnic divisions.

\section{Publisher's Note}

Springer Nature remains neutral with regard to jurisdictional claims in published maps and institutional affiliations.

Acknowledgements Not applicable.

\section{Funding}

Not applicable.

\section{Availability of data and materials}

Available from the author upon request.

\section{Ethics approval and consent to participate}

Not applicable.

\section{Consent for publication}

Not applicable.

\section{Competing interests}

The authors declare that they have no competing interests. 


\section{References}

Wu, Xiao. 2013. An analysis of the mechanism of the initiative on promoting inter-ethnic unity and common progress under the vision of governance theory 试析治理理论视野下的民族团结进步创建机制. Career Horizon 《职业时空》12: 131-134.

Yan, Qing. 2019. The evolution and characteristics of the chinese inter-ethnic unity中国民族团结的意涵演 化及特色. Ethno-National Studies《民族研究》1 (24-34): 138-139. 